\title{
Recognition and Indeterminacy: A Psychoanalytic Reading of Illegals Acts in Adolescence
}

\author{
Jacqueline de Oliveira Moreira1, Andréa Maris Campos Guerra², \\ Aline Souza Martins ${ }^{3}$, Ana Carolina Barbosa Cadar", \\ Angela Bucciano do Rosário 5 \\ ${ }^{1}$ Pontifical Catholic University of Minas Gerais, Belo Horizonte, Brazil \\ ${ }^{2}$ Federal University of Minas Gerais, Belo Horizonte, Brazil \\ ${ }^{3}$ Psychology Department, College Anhanguera, Osasco, Brazil \\ ${ }^{4}$ Psychology Department, Établissement Public de Santé de Ville Evrard, Neuilly-sur-Marne, France \\ ${ }^{5}$ Psychology Department, University President Antonio Carlos, Barbacena, Brazil \\ Email: jackdrawin@yahoo.com.br, andreamcguerra@gmail.com, alinesouza.martins@gmail.com, \\ anabcadar@gmail.com, angelabr@ig.com.br
}

Received 30 July 2015; accepted 25 September 2015; published 28 September 2015

Copyright (C) 2015 by authors and Scientific Research Publishing Inc.

This work is licensed under the Creative Commons Attribution International License (CC BY).

http://creativecommons.org/licenses/by/4.0/

(c) (i) Open Access

\section{Abstract}

The article aims to raise and develop a hypothesis about the problem of teenage violence in illegals acts. We understand violence among adolescents as a phenomenon sustained by a circuit of segregation and the seeking for recognition, using the idea of recognition as a conceptual operator, created by Honneth from the Hegel. The main hypothesis is if illegal acts of adolescents are linked to the various stages of recognition, it includes an uncatchable field of indeterminacy. The discussion about recognition from the notion of indeterminacy, through the scope of a psychoanalytic lens, suggests that illegals acts and aggressiveness can be heard not only in the psychoanalytic practice, but also in social manifestations.

\section{Keywords}

Adolescence, Illegal Acts, Recognition, Indeterminacy, Psychoanalysis

\section{Introduction}

The Brazilian contemporary society is troubled with issues of violence in large urban centers, mainly violence caused by adolescents. Society's concerns become real in the media, in the people's anger and in the movement 
to reduce the age of majority. It is clear that this also concerns researchers of different fields of study. The plethora of scientific articles that address the themes of adolescents and illegal acts (Lemos, 2009, Arantes, 2009, Miraglia, 2005, Minahim and Spostato (2011); Mello (1999); Balaguer (2005), Moreira, Rosário, \& Costa (2008); Guerra et al. (2010), confirms the importance of the topic in the scientific community.

In an investigation about the topic in Brazilian scientific magazines, fifty nine (59) articles are found through Scielo and Pepsi, which present the perspective of psychology and other human sciences in period of 2000 through to 2012 that work on this issue. The search key words used are: adolescence, socio-educational measures, adolescents in conflict with the law, ECA (Child and Adolescent Statute), adolescent offender, adolescent criminal offence perpetrator. After reading the articles, they are visualized in three categories: 1) socio-cultural: articles: they looking for comprehensive hypotheses about the youth violence phenomenon, therefore they seek psychological and social determinants in the phenomenon's source; 2) political-institutional: this group produces critical analyses about the laws and socio-educational institutions, reflecting about the process of legislative construction, its implementation and the effects of its history in the institutions responsible for their execution; 3) finally, the practical-experiential articles that report local experiences. Although the three cate-gories being covered are important and supported, for this article it is important to prioritize the socio-cultural perspective and try to find comprehensive hypotheses about the issue (Moreira et al., 2014).

\section{Literature Review}

On the revised literature, starting from Vorcaro and Monteiro (2008) who focus their analyses on the discussion of the presence or absence of the father in the contemporary family structure, which nowadays is organized as various different compositions. They call into question the deterministic perspective that assign the father's concrete absence as one of the causes of youth violence issues. They conclude that given the difference between the father's concrete absence and the Name of The Father's enrollment failure, while it may be a symbolic factor for the child's cultural development, the causality is not confirmed. The variations of subjective responses to this symbolic factor are unique, therefore not allowing a generic universal assertion. As can be seen on the following passage:

The relationship of individuals with their parents during their childhood provides the structure for the other relationships that will be established throughout one's life. However, according to Lacan's (1995 [1956-57]) description in "The Object Relations", the construction of maternal and paternal functions, as well as their effect, do not equate to the mother and father themselves, but refer to what was passed down to the subject as the referential ideals of these functions. The absence of a concrete father figure will certainly implicate a specific characteristic in the individuals' life. This is known and unquestionable. The issue is to know if this specific characteristic will determine the undertaking of illegal acts later in life. Psychoanalytic theory discusses the singularity of each case. Through it, it is known that the influences of certain events will depend on how the individual will take it, according to his background (p. 136).

Consistent with the citation above, Moreira, Rosário, \& Costa (2008), believe in an interdisciplinary review. The authors articulate sociology's ideas in relation to consumer society's appeal with concepts of psychoanalyses that work on the subject of the violence in the relationship between the self and the other. By adding the philosophical notes about post-modernity to these two fields, the following conclusion can be made:

After all, in order to meet at the critical point in historic transition, contemporary adolescents become heralds of a new model of society. Thus, for exposing the failure of old values, their symptoms can be the key to a new era, regulated by new ideas, of which Modernity's outdated lens have prevented one from seeing (Moreira, Rosário, \& Costa, 2008: p. 1044).

Authors such as Spagnol (2005) and Guerra et al. (2010) also share that the understanding of the symptom of adolescents in vulnerable situations are an act to be listened to and recognized in a broader perspective. Spagnol (2005) attempts to understand the phenomenon of juvenile delinquency through a sociological perspective, stating that poverty alone does not explain violence in the peripheries. The author believes that the use of "violence appears in the shape of higher form of expression" (Spagnol, 2005: p. 279) and "youths who commit a violent act seek to reverse the visible signs of the social integration's disadvantages” (Spagnol, 2005: p. 291).

For Guerra, Moreira, Lima, Pompeo, Soares, Carvalho, \& Pechir (2010) the explanation of the link between 
youth from urban areas and violence must be interdisciplinary and not reduced, pointing to the hypotheses of the crime as a means of social bonding. Therefore, the causes of the involvement of youth in crime can be found in their own story, which can be inserted in a specific sociocultural and symbolic context. The authors verify that the discursive elements such as belonging to the community, parenthood, loving or sexual bond and insertion in the crime may serve as elements that activate or deactivate the social bonds, in a discontinuous and unstable manner.

Representing other approaches, Jost (2010) uses phenomenology and Monte, Sampaio, Rosa Filho, \& Barbosa (2011) rely in Piaget's theory of development in order to understand the issue. Jost (2010) seeks to understand through qualitative research the motivations that promote the illegal acts. According to the author, these adolescents "live the anguish of uprooting, of not belonging, of loss of references and values, which are characteristic of an existential crisis" (Jost, 2010: p. 106). Monte et al. (2011) on the other hand, based on the reflections of development of the moral conscience, seek to analyze the current legislation that refers to adolescents that commit illegal acts. They conclude that the documents are consistent with the literature on the development of moral consciousness, however "the analyses about the reality of the Brazilian institutions of re-socialization of adolescents who have committed illegal acts point to serious structural and educational problems” (Montes, 2011, p.131).

\section{Discussion}

\subsection{General Premise}

From the reading and analyses of these papers, an element that is highlighted and repeated through different fields of study that addresses the topic of adolescents and illegal acts is faced: recognizing and segregation. The study points to the predominance of theses, which seek to understand and/or analyze the situation of the infractions among adolescents as a phenomenon fueled by a circuit of segregation and the search for recognition. Therefore, this article will be dedicated to engage the issue of recognition within the universe of the study of illegal acts. For such, a deep theoretical-conceptual analysis of this category will be made along with the thoughts generated by the research. Starting from the violence phenomena articulated by the theme of segregation, using as a conceptual operator the idea of recognition. Explained by Célio Garcia's sentence, cited by Vorcaro, Mazzinni, \& Monteiro (2008): "The life of crime [...] is severe, violent and insecure: however, it offers temporary and unstable peace of everything that wishes to be recognized” (Garcia, 2000; Vorcaro, Mazzinni, \& Monteiro, 2008).

\subsection{The Recognition}

The Frankfurtian philosopher, Axel Honneth, is the one that provides the first clue for us the phenomenon's analyses, stating that:

Hegel attributes the origin of a crime to the fact that the recognition has been incomplete: in this case, the internal motive of the criminal is constituted by the experience of not being recognized in a satisfactory manner in the established stage of mutual recognition (Honneth, 2003: pp. 52-53).

The Hegelian thought associates crime to the lack of mutual recognition. Therefore, there is a continuous connection between the moral disrespect and social struggle (Gadea, 2006). The expectation to struggle for recognition begins when disrespect comes with experiences that prevent the personal identity formation, a subjective inter-reaction process of struggle for mutual recognition. Honneth (2003) sees in crime a representative of the act, which is a consequence of an injury in the "universal-recognized being". For the author, what would be achieved in a crime (in an advanced stage of rights), the same as the struggle between life or death. Under the conditions of the process of individual formation: the subject seeks, by a provocative action, to make another individual or the many associated with it to respect what has not yet been recognized in its own expectations for the forms of social relationships" (p. 101).

Honneth reviews the Hegelian thought in which he presents three dimensions that are found in different stage and that present a co-dependence relation: the emotional stage or love, the legal-moral and social esteem. The emotional stage allows personal self-realization projects and is connected to family relationships: the legalmoral dimension is responsible for the recognition of the autonomy; and the social esteem stage, which is responsible for generating solidarity. 
According to Nobre (2003), only in the two last stage exists the possibility of the struggle to be shaped as a social conflict. Because in the first stage, there is the establishment of the "first social relationships as a process of distancing the individuals from the natural determination" (p. 49). The Hegelian thought sees the "relationships of 'parents and children"” as a "universal reciprocal action for the formation of men" (p. 49), in which the individual, upon receiving the acceptance of another, realizes himself as one of needs. It can be said that the recognition under the law, which constitutes the second stage, is intimately related to the emotional stage, representative of the first form of the individual's socialization and located in the family. It is through love and the perception of ones needs as a structure by the closest people, in which the individuals are able to expand the relationships for society. According to Honneth (2003):

The path that conducts a new social relationship is described as a universal judicial process: the practical relationships that the individuals already had with the world on the 1st stage are ripped out of their merely particular validity conditions and transformed in universal rights claims guaranteed contractually (p. 50).

Therefore, the recognition socialization movements perform a dialectical operation in relationship to the particular recognition that is found within the family. Some elements are preserved while others are outdated. However, due to the excess of particular family recognition, the authors consider that the crime, in the strict sense, can only "be thought as an action that seeks to disregard the 2nd stage of recognition” (2003, p. 53).

In that regard, Honneth (2003) states the origin of the crime for Hegel is found in the fact that the recognition is incomplete. The author asserts that for the philosopher the aggressive action in which the excluded individual responds to does not attempt to damage random property for the satisfaction of their sensitive necessities. The destructive reaction of the one who has not been recognized seeks to make himself known again. In other words, an act in which its true objective is to recover the other's attention.

The excluded one damages the other's possessions, he places his exclude "relation to-self" in his act. He destroys something in that, as the annihilation of the desire, in order to give himself the feeling of ownership, not the feeling of his empty self, but by putting himself in another self, in the knowledge of another

(Hegel, 2003; Honneth, 2003: p. 88).

In other words, the action of the excluded individual intends to "not the negative, the thing, but the selfknowledge of the other" (Hegel and Honneth, 2003).

Hegel, in Honneth's reconstruction wouldn't deny the existence of "crime" linked to the first stage of recognition, but points to the action as an act of destruction in which "the individuals reacted aimlessly to the "abstraction' experience of already formed morality” (p. 53). Therefore, the hypotheses is formulated stating that the adolescents' illegal acts can be linked to different stages of recognition and reveal a deadly face of social segregation , including in its interior a field of uncatchable indeterminacy.

It is important to highlight that reducing the topic of juvenile crime to the possible forms of refused recognition in the family scope is not this paper's interest. Precisely because considering the cited authors, the strict definition of crime is linked with the second and third stages of recognition. Besides that, the crime phenomenon is not believed to have causal univocal linearity, whose complexity approximates to the sum of the vectors that cross in a relational composition of their social result. Therefore, there are no doubts that the illegal acts could express the desire of recognition in the juridical-moral stage, since it is a truth that these individuals only enjoy their rights when they are responding to socio-educational measures. However, considering the phenomenon's relational perspective, the theme of recognition is where the focus will be favored.

This reflection is concerned because it is understood that the individual that faces the refusal of the most basic form of recognition may find himself excessively vulnerable and may seek social recognition in the act. Certainly if the adolescent's action has the goal of being noticed by someone, if they seek to be seen, it may be suggested that the act emerges as a symptom that needs to be heard. In which it is inquired, if the other's attention, captured by the illegal act, will provide recognition. In addition, which recognition could society offer to these adolescents, as well as what would be the effectiveness of this delayed recognition.

\subsection{The Indetermination}

If it is understood through Hegel that the Man is necessarily recognized and necessarily a recognizable being, he constitutes as a recognizer, therefore, 
[...] the development of the auto-conscience depends on the existence of a second subject; without the experience of a partner in the interaction that reacts to him, the individual would not be in conditions to influence on himself based on the auto-perceptible manifestations (Hegel, Honneth, 2003, p. 131 emphasis added).

It is important to emphasize the word reacts in the citation above. The reaction is understood as a movement that necessarily implies the presence of the other in a particularly active manner. It is in this bias that Honneth inserts Winnicott's psychoanalysis approach, to think of the struggle for recognition, emphasizing on the object relations present in the theoretical construction of this psychoanalyst.

Winnicott describes the baby's psychological development from successive stages, which takes place in a gradual manner, starting from absolute dependency to the mother or her substitute until their separation. However, the lack of, (as understood in Lacan's theory) is constituted during the baby's development, "allowing the child to support the disillusion and to realize the Other's incompleteness" (Costa, 2007: p. 55). It is the care continuity that, for Winnicott, will give to the child its psychological sustenance.

Therefore, it is based on Winnicott's studies that the author will outline the fundamental principles of the first level of recognition: love. In this direction, the fact that Hegel supposes love as the structural core of all ethics is reminded by Honneth:

Only that symbiotically fed connection, that comes from the mutually wanted delimitation, creates the individual self-confidence measurement, which is the essential base for the autonomous participation in public life (p. 178).

Therefore, the first form of reciprocal recognition is rooted in the emotional security made possible by the inter-subjective experience of love, which "constitutes the psychological precondition for the development of all other self-respect attitudes" (p. 177). In the words of the author:

The form of love recognition that Hegel describes as "to be itself in another", does not designate an intersubjective state, but designates an arc of communicative tensions that continually mediate the experience of power-to-be-one with the to be-fused. The referentiality of the self and the symbiosis represent the required counterweights that taken together enable a reciprocal being-with-self with the other (Honneth, 2003: p. 175).

How would the lack of such recognition in the primary family level, in which something from the love transmission and the ethics were incomplete be is something to be thought of. In that sense, Lacan takes a new step. For him, it is about the structure of the lack of an object and not the relation of the object. Going back to Freud, the idea of object relations is, in itself a paradox. Freud isolates the moment of the loss of object from the moment of its reencounter. With that, not only the mythical character of this loss is marked, but also the impossibility of reencounter with the lost object. In the text of Three Essays on Theory of Sexuality (Freud, 1962 [1905]), refers to the transformations of puberty and considers the latent memory in this period about the first hallucinatory experience of satisfaction. Freud states that the relationship model with a primal object (the mother) and it's recollection is irreversible in the sense that the object will always be rediscovered, marked by the style of the first object. Thus, the insurmountable gap between what is sought for and what is founded. Hence the structural relationship to be with the lack of the object, and not with the object itself. Therefore, Lacan refers to the idea that for Freud the object is apprehended through the search for a lost object, the tendency of an object to rediscover itself, the object that was initially the point of satisfaction in the first childhood experiences.

Nostalgia bind the subject to the lost object, through which it exercises the entire search's effort. She marks the rediscovery of the repetition of an impossible sign, since, precisely, this is not the same object, and neither could it be so. The primacy that this dialectic puts, in the center of the subject-object relationship, is a fundamental tension, which causes what is sought and not sought for in the same manner of what is reencountered. It is through the search of a passed and outdated satisfaction that a new object is sought for, found and apprehended elsewhere and not at the point where it is sought. There exists a fundamental distance, introduced by the essentially conflictual element included in all object search (Lacan, 1995 [19561957]: p. 13).

Right from the start, Lacan points to the naivety in believing in a symmetry between the object that is sought 
out for and the one that is found. If it comes to the object relationship in psychoanalysis, this can only refer to the absolute lack of the object. It is through the recognition of the mother's castration, the other's castration to wit, the absence of the object that would make one complete allows one to find the object in it's lacking function and, therefore, in the cause of the desire. One only desires that which remained lacking...

It is known that the subject at birth is introduced into a pre-established order that precedes and determines itself, and in the attempt to apprehend it, the relationships with the lack of the object will produce its effects. If subjected to a pre-existing order and needing language to establish any relationship with the world, the disharmony will already be the mark of any bond that one may establish with the object.

The enrollment of infans in the Culture will occur from the manner it has been operated the passage of the same relation as the castration complex in the Oedipus, of which crossing and transmission will start from the family unit. For beyond the a-a' imaginary relationship, that assumes a specular reciprocity, the Oedipus complex introduces the S-A relationship, which through the symbolic aspect, marks the recognition of the mother's castration and, consequently, the impossibility of satisfying one's desire. Then, in this position of puncture, it's presented the attempt of apprehension or construction of the reality through the Language, of the significant unfolding. The language tries to deploy to the significant, which is elusive and represented by the other's desire by an object forever lost in phallic representation.

In this manner, the lack of the object is the spring that sustains reality, the relationship of the subject with the world (Figure 1).

In "Note on the Child”, Lacan (1990 [1969]) indicates that this transmission is done through the family:

The function of residue that the conjugal family sustains (and by the same stroke maintains) in the evolution of societies emphasizes what is irreducible in a transmission - which is of another order than that of life according to the satisfaction of needs-but which is of a subjective constitution, implicating the relation with a desire that is not anonymous (p. 369).

In this case, the lack of the object as a cause becomes operative on the ethical plane, in the extent that the desire is articulated from the Law that regulates it. In this plane, the family function is the transmission of culture, in other words, the form of a sublimation of the drive, which barrier is the desire. Therefore, it is it, the family, the first vector of ethics transmission.

In this sense, returning to the importance of the first level of descriptive recognition by Honneth rooted in the possibility of the inclusion of a reference in the subject that will highlight their actions throughout life. This reference will guarantee the possibility of an alterity encounter that would necessarily imply in a relationship of mutual recognition. It is necessary, however, to include the dimension of alterity of the subject with their other, established through the relationship with the lack of the object, not foreseen by Honnet. Divided by the desire (Freud, 1940 [1938]), searching for the satisfaction in the recovery of the lost object of the first libidinal satisfactions, but never reencountered, a part of itself is unknown to the subject, having between instances of their psyche alternations, disagreements, conflicts and tensions. From the attempt to handle this reality, through the appointment of which is lost in the encounter of body and language, the subject becomes a stranger for itself: a double that gives it an unrecoverable unit, an indeterminacy field pushing its relationship with the other (Freud, 2003 [1919]).

The construction of the self starts from the gaze of the other, specular, which find that subject as an anticipated unit (Lacan, 2006 [1949]). The joy that the infans find in this image is realized in the specularity there

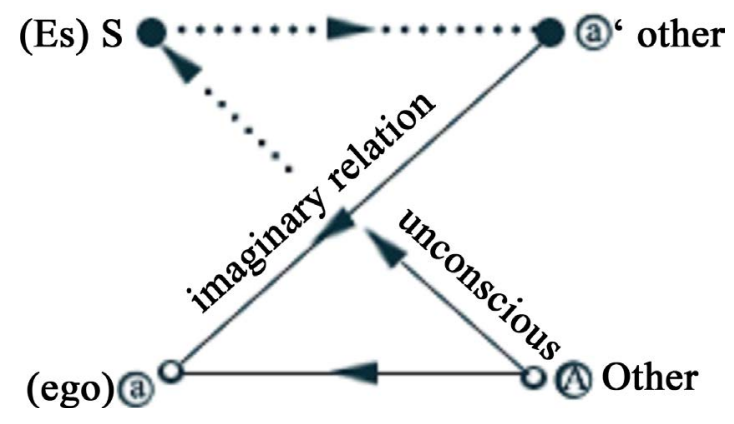

Figure 1. Lacan (1993 [1981]). 
projected through the other's gaze. That is, between the subject and its image interposes the other-strange and desiring gaze that institutes the lack of the object. From the alienation to this image, the separation process arises at which point the self will be instituted, containing a stranger in itself. The intensity of the separation process is fed by the specular equivalence between the subject and the anticipated image arising from the other. This process is incited by the structural aggressiveness of the imaginary dimension presented in the dual relationship, animating the separation between the subject and the other. There is however, in the reciprocity between the subject and the other, a field of indetermination and at the same time, a crucial determination for the subjective constitution and the composition of its response to the recognition process.

In the act of separation of the alienating image from the other, the subject recognizes as self all that refers to pleasure and as not-self everything connected to displeasure. Projecting, however, in the other the worst, the unpleasant, their subject highlights. Therefore, the act of separation carries a certain quota of destructive aggressiveness so that the subject can stand out from the gaze of the other, constituting its own body, duplicated from this original image-supported therein, but not all matching to it. In this hiatus, seamlessly between the self and the self's image, lies the drive dimension that resists the signification and significant determination.

It is important to emphasize that the problem of illegal acts in adolescents is found there, because it is understood that adolescents is a vulnerable moment in the subject's life, since it solicits a new instinctual organization. The subject crosses a conflictive moment initiated by the gradual substitution of the child's body, of which was identified, for a sexual body, increased libido competing with the distancing of oedipal objects and the choice of a new non-incestuous sexual object, culminating in the effective entry into social dialectic (Freud, 1962 [1905]). In this manner, the adolescent who commits the illegal act, when approaching the victim, could be seeking the usurpation object, since without the imaginary relationship of reciprocity and with the real encounter with the lack of the object, the symbolic exchange is impossible. Therefore, the illegal act is opened as a concrete possibility, since the lack of structural reciprocity in the originating act of recognition is interpreted as a refusal of the other, generating suffering.

According to Safatle (2012) Lacan himself would come to the understanding that "psychological distress is linked to the deficits of social recognition” (p. 5). And here it can be thought exactly, not the recognition of the subject within a reciprocally constructed identity, but precisely the subject in this field of indetermination.

This suffering can take form, for example, of the incapacity to live non-identity and indetermination experiences (which takes, pure and simply, the incapacity to live experiences as events), or of isolation of those who do not find any more traces of others in their own temporal experience (loss of historicity) and of the compulsive link to the current image of men (Safatle, 2012: p. 6).

Therefore, it is not so much in a field of identities but more so in the recognition of alterity for what is suspended in social norms, in other words, for the a-normativity. This concept has as an advantage the incorporation of disruptive aggressiveness, expressed many times through the illegal act, for a theory of being and its consequential extrapolation for the social bond. This manner of conceiving one's self without denying the aggressiveness inherent to the construction and deconstruction processes of the social norms brings a new role for the social action and for the State. Including the indetermination, the State appears to be facing a seemingly contradictory function:

It should accommodate the indeterminacy experiences that inhabits the individualities, and must provide the necessary determinations for the accomplishment of the autonomy through the establishment of a set of universal positive laws (...). He, at the same time, created institutions and generates the indetermination. To be clearer, for Hegel, the State is an institution capable to generate indetermination, to get over it without simply denying it (Safatle, 2012: p. 86).

This discussion allocates to the problem of the adolescent in conflict with the law a new dimension as the recognition. It introduces a new non-restitutive and non-retributive logic, but before the logic of implication and responsibility, which affects the youth, State and civil society as pairs in the same process. If the identity logic prevails in detriment to the recognition that assumes identity and alterity, this process can come to intensify the specularity and the difference, culminating, therefore, in the aggressiveness and the segregation and not in the dialectic overcoming of differences. The ethics of responsibility, for its part, engages the subject and the civilization in terms of the structural indeterminacy that affects both parties. In this sense, social symptom can be talked about. 


\section{The Social Symptom and Non-Recognition}

In order to understand the "social” qualification attributed to the notion of the symptom, it is also necessary to understand that the individual's dimension is also social (Freud, 2005 [1921]). The social responds to the bond that the subject establishes with the other. Such study follows the indication that Freud (2002 [1930]) in "Civilization and Its Discontents" and in "Totem and Taboo" (1918[1913]), where he establishes a parallel between neuroses and the social other. It is important to highlight that the social symptoms of Freud's century are not the same as the contemporary ones. It's important to highlight that sexual repression during the Victorian Era had a different focus on bodies, which today are exposed to a jouissance that presents itself in a different and urgent way. Each era is taken by the plus-de-jouir in their own way. However, independently of their new symptom expressions, remain with the discontent that is irreducible and goes through time and culture. Arthur Rimbaud's "true life" seems today like the term used by the adolescents in the slums ("vida loka"), which propel to an uncontrolled jouissance and in some cases to violence.

This historical difference can be put from the alliance of the capital and science, which articulates the bodies and their presence in the social pact. In contemporary times, consuming a product is an inclusion experience, because by consuming a brand, the subject has the possibility of being recognized, to exist in the social structure. All the objects are acquirable, essential and disposable, (un)organizing the subject's life when offering a large plurality of ideals.

This context provides a violent buoyancy to the jouissance in the form of consummation and suffering. The Discourse of Capitalism and consummation, coupled with the genetization and biologization of the behavior, just scrap a presumed freedom and equality of rights. The contemporary social bond experience indicates new bindings shaped by the violent exercise of capital emancipation that substitutes the subject's demand for the one of the consumer objects (Catroli, 2003; Rosa, 2004). However, the consumer circuit is autistic and dispenses the entry of others in the reciprocal circuit, founding itself in the self-sufficiency of individuals in the enjoyment of gadget objects. In this sense, the social bond is marked by the liquidity of their articulation, weakened by the typical and contemporary immediacy and hedonism.

Bauman (2000) supports this reading while explaining the process of globalization. One lives in the era of speed and mobility. The frontiers are soluble, diluted by the flow of information and economic and political negotiations. Mobility has become a powerful hierarchical order of globalized power. Strengthening this discussion, in the Television, Lacan (1980) presents the Discourse of Capitalism, the degenerated version of the Discourse of the Master. The Father, dismissed from his role, gives room to a new logic, in which the consumer is also consumed by the destabilized social bond. The law of the desire makes room for the market law. Under the aegis of such social functioning, what can be said about the subject in the social bond? Could one talk in symptom or even social symptom as a response to the non-recognition? What would configure the social symptom?

In order to analyze the relationship of the non-recognition and the social symptom, going back to Moreira, Rosário, \& Costa's (2008) idea of the adolescent as a herald of a new form of social bond. The youth who commit an illegal act commonly do not have access to the market's products, but are not excluded from the capitalist logic. The capital machine marginalizes them and maintains them as leftovers. In this scenario, psychoanalysis emerges to question how each adolescent responds to this context.

In the subject-other dialectics, Lacan defined the symptom as a particular way that the subject can find pleasure in their unconsciousness, but itself is only a symptom as it forms a relation with the other. If the bond with the other appears to be fragile and opaque, if there is no room for recognition, it can the thought in terms of the social symptom. The social symptom has its roots in the subject, but changes its configuration according to the context in which its inserted. Within that same logic, the non-recognition of adolescents in conflict with the law can be understood as a social symptom. The non-recognition can be seen as both planes: the primary, or family plane, founded in love and transmission, or the social plane, when the non-recognition is noticed in the juridical, moral sphere and in the social esteem.

According to Broide:

Drug trafficking has strict rules, it recognizes a job well done and an adolescent's knowledge, and even offers a career path. It allows access to the emblematic globalization products such as clothing brands, weapons and money, which mean access to sexuality, high status and respect from their peers, besides capturing the youth in the imaginary of potency (...) (Broide, 2012: p. 130).

Will the youth finally be recognized by being in the spotlight? They may get to be known by their actions, but 
do not reach recognition. They create a new form of symptom society. According to Lacan (2007 [1991]), the social symptom emerges when each individual is in the condition of the proletarian, in other words, does not have a discourse to establish a social bond or semblant. It is interesting to note that the use of the term proletarian, which indicates the contemporary proletarian, lacks knowledge of their own products, alienated to a different knowledge that legislates over them. Here the symptom definition offered by Marx is approached, of which formation depends on the subject's ignorance of his own knowledge to produce goods in the capitalism system.

The subject can only make something of his jouissance in the measure that it escapes him, therefore, not only the subject is ignorant to such, but they also do not become present in the social bond, but alienated to the truth of the master it serves and whose knowledge supports with their work. About this subject, it is understood that it is not recovering the lost recognition in the different stages described by Honneth (2003). What is verified in this alienating process is that it finds a new manner to allocate his jouissance in the system. It is exactly when their jouissance becomes a product of the discursive system of a time (a vailed truth that maintains it), that the subject allocates into it. There is however a paradox in this recognition that is therefore produced: it is exactly when it alienates himself from his own truth, (and from his position as a subject that desires something), that the youth falls into the recognition circuit. This is a complex paradox, since it involves a dimension of indeterminacy in its interior, as the core agent of the interpretation of the phenomenon.

\section{Conclusion}

This discussion about recognition from the notion of indeterminacy institutes the possibility of conceiving politics not as an attempt of normalization, but as a "space in which a man unceasingly seeks recognition in inhuman manners, in a pitch-dark world that demands one to go as far as the image itself does not reach" (Safatle, 2012: p. 234). This is the possibility for the inhuman and the animality, the impersonal and the anomaly that are dimensions of the mankind could be recognized as a constituent subject of the human being, making room for both social and personal manifestations entailing change and desire. Therefore, the illegal act and aggressiveness inherent to one can be listened to not only in the psychoanalytic clinic, as admonished by Freud and Lacan, but also in social manifestations and institutions.

Concluding, this project ends representing the appeal to a renewed praxis of politics with the help of psychoanalysis, capable of opening ones ears to the fight for recognition behind the illegal acts of adolescents. This new approach does not contenting itself with the normative moral and the traditional social bonds, seeking to hear what the aggressiveness pursues to write in the story through its manifestations, so that, at some interval, this aggressiveness can become dispensable or less necessary.

\section{References}

Bauman, Z. (2000). Globalization: The Human Consequences. New York: Columbia University Press.

Broide, J. (2012). Adolescence and Violence: The Creation of Clinical Devices in the Agitated Areas of the Suburbs, In R. Em Gurski, M. D. Rosa, \& M. C. Poli (Eds.), Debates about Contemporary Adolescence and the Social Bond (p. 123-136). Curitiba: Juruá.

Costa, T. (2007). Psychoanalyses with Children. Rio de Janeiro: Zahar.

Freud, S. (1918). Totem and Taboo (1913). New York: Moffat Yard and Company.

Freud, S. (1962). Three Essays on the Theory of Sexuality (1905). Trans. James Strachey, New York: Basic Books.

Freud, S. (1976). The Negation (1925). Edição standard brasileira das obras psicológicas completas, XIX, 293-301

Freud, S. (2003). The Uncanny (1919). Trans. James Strachey, New York: Basic Books.

Freud, S. (2005). Massenpsychologie und Ich-Analyse. Die Zukunft einer Illusion (1921) (Group Psychology and the Analysis of the Ego: The Future of an Illusion). Frankfurt-on-Main: Fischer Verlag. (In German)

Freud, S. (1940 [1938]). Die Ichspaltung im Abwehrvorgang. Internationaler Zeitschrift Psychoanaltischer. Imago, 25 XXV, 241-244, GW, XVII, 57-62, Splitting of the Ego in the Process of Defence. SE, 23, 271-278.

Freud, S. (2002). Civilization and Its Discontents (1930[1929]). London: Penguin.

Gadea, C. A. (2006). Review of “Struggle for Recognition”. Ciências Sociais Unisinos, 42, 72-73.

Guerra, A. M. C., Moreira, J. O., Lima, N. L., Pompeo, B. D. S., Soares, C. A. N., Carvalho, L. M. S., \& Pechir, N. A. N. (2010). Building Ideas about Youth Involved in Violent Crime. Estudos e Pesquisas em Psicologia (online), 10, 434-456. 
http://pepsic.bvsalud.org/scielo.php?pid=S180842812010000200010\&script=sci_arttext\&tlng=en

Honneth, A. (2003). Luta por reconhecimento: A gramática moral dos conflitos sociais (34th ed.). Trad. de Luiz Repa, São Paulo: Ed. 34.

Jost, M. C. (2010). Phenomenology of the Motivation of the Adolescent in Conflict with the Law. Psicologia: Teoria e Pesquisa, 26, 99-108.

http://www.scielo.br/scielo.php?script=sci_arttext\&pid=S0102-37722010000100012\&lng=en\&nrm=iso

Lacan, J. (1980). Television: A Challenge to the Psychoanalytic Establishment. New York/London: W. W. Norton \& Company.

Lacan, J. (1990). Note on the Child (1969). In R. Grigg (Trans.), Analysis (No. 2). Melbourne Centre for Psychoanalytic Research, Deakin: Deakin Printery.

Lacan, J. (1993). Book III: Les psychoses (Seuil, 1981). New York/London: Routledge/Norton.

Lacan, J. (1995). La relation d'objet (S IV) (1956-1957). Paris: Le Seuil.

Lacan, J. (2006). The Mirror Stage as Formative of the Fonction of the I as Revealed at Psychoanalytic Experience (1949). In B. Fink (Trans.), Écrits: The First Complete Edition in English. New York/London: W.W. Norton and Company.

Lacan, J. (2007). Book XVII: L'envers de la psychanalyse (Seuil, 1991). New York/London: Norton.

Monte, F. F. C., Sampaio, L. R., Rosa Filho, J. S., \& Barbosa, L. S. (2011). Adolescents Undertakers of Illegal Acts: Moral Psychology and Legislation. Psicologia \& Sociedade, 23, 125-134. http://www.scielo.br/scielo.php?script=sci arttext\&pid=S0102-71822011000100014\&lng=en\&nrm=iso http://dx.doi.org/10.1590/S0102-71822011000100014

Moreira, J. O., Guerra, A. M. C., \& Drawin, C. R. (2014). Brazilian Scientific Production on Socio-Educational Measures and Adolescence (2000-2012): Preliminary Considerations. (Unprecedented)

Moreira, J. O., Rosário, Â. B., \& Cosata, D. B. (2008). Youth Crime in Post-Modern Brazil: Some Psychological Reflections about the Violence Phenomenon. Revista Mal Estar e Subjetividade, 8, 1021-1046.

Moreira, J. O., Souza, J. M. P., Rocha, P. M., Guerra, A. M. C., \& Peixoto, M. L. V. L. (2014). The Challenges in the Application of Socio-Educative Measures in Brazil: A Reflection on Different Reports of the Latin Psychological Experience. Psychologia Latina, 5, 1-10.

Rosa, M. D. (2004). The Psychoanalytical Research of the Social and Political Phenomena: Methodology and Theoretic Substantiation. Journal of Discontents and Subjectivity, IV, 329-348.

Safatle, V. (2012). Grand Hotel Abyss: For a Construction of the Theory of Recognition. São Paulo: Martins Fontes.

Spagnol, A. S. (2005). Young Paulistano Offenders. Tempo Social, 17, 275-299.

Vorcaro, A., Mazzini, C. A., \& Monteiro, J. P. (2008). Illegal Acts and the Paternal Metaphor. Psicologia: Teoria e Prática (Online), 10, 135-146. 